\title{
Multicriteria Tools for the Implementation of Historic Urban Landscape
}

DOI: 10.12776/QIP.V21I1.792

\author{
Antonia Gravagnuolo, Luigi Fusco Girard \\ Received: 17 September 2016 Accepted: 3 December 2016 Published: 30 April 2017
}

\begin{abstract}
Purpose: The aim of this paper is to provide an overview and critical outlook of current evaluation tools for the implementation of the UNESCO Historic Urban Landscape (HUL) approach, focusing on the need of multidimensional / multistakeholder evaluation and impact assessment to turn heritage / landscape into a driver of sustainable development.
\end{abstract}

Methodology/Approach: We analyse the definition of Historic Urban Landscape comparing the thoretical mandate to current tools / practices. Based on literature review and critical analysis of recent experiences, we identify indicators categories and evaluation methods that can be applied for a reacher cost-benefit analysis.

Findings: Indicators and evaluation methods for multidmensional impact assessment of conservation / regeneration are not applied in HUL recent initiatives and guidelines. Evaluation tools can be developed and tested to inform decision-making processes and to turn the cultural value of heritage / landscape into a resource able to attract investments. A framework for HUL impact assessment can be structured including wellbeing indicators and stakeholders analysis.

Research Limitation/implication: New hybrid tools are proposed, providing a possible toolkit for evaluation. However, it needs further testing and implementation.

Originality/Value of paper: This paper contributes to bridging the gap between the theoretical approach of the Historic Urban Landscape and its operative practice. The HUL approach has been generally acquired in the theoretical research, but its implementation is still sporadic, and unframed into urban regeneration policies. Evaluation tools are not incorporated in the HUL practices. 
This paper aims to advance the existing knowledge on evaluation tools to make operational the HUL approach.

Category: Research paper

Keywords: Historic Urban Landscape; evaluation tools; impact assessment; cost-benefit analysis; multidimensional indicators

\section{INTRODUCTION}

Urban heritage conservation in rapid transformation contexts is a great challenge for today's cities (Bandarin and Van Oers, 2012; Bandarin and Van Oers, 2014). There is an urgent need of adequate services and infrastructure for millions of people expected to migrate to urban areas in the next decades.

Cities can be engines of economic growth of regions and countries, but also places of poverty, social segregation and fragmentation of relationships, diseconomies and pollution (Fusco Girard, 2014a). Recent outcomes of international meetings and working groups on urban sustainable development highlight the role that cultural heritage can play in enhancing living conditions, social cohesion and cultural diversity in cities, thus contributing significantly to wellbeing and prosperity (European Commission, 2014; United Nations, 2015; UNESCO, 2015). Conservation and regeneration of urban heritage could be considered a key investment for sustainable local development (Licciardi and Amirtahmasebi, 2012; Van Balen and Vandesande, 2016), but sound methods and tools for the evaluation of the economic and social / environmental impacts of heritage-led urban regeneration are still lacking (Ginsburgh and Throsby, 2014; Throsby, 2016).

The 2011 UNESCO Recommendation on the Historic Urban Landscape (UNESCO, 2011) recognize the need of supporting the protection of cultural and natural heritage in rapid and uncontrolled urbanization contexts, integrating the notion and value of transformation in heritage integrated conservation strategies.

The definition of Historic Urban Landscape (HUL) considers the "historic layering of cultural and natural values and attributes, extending beyond the notion of 'historic centre' or 'ensemble' to include the broader urban context and its geographical setting" (Art. 8). It includes "perceptions and visual relationships", "social and cultural practices and values, economic processes and the intangible dimensions of heritage as related to diversity and identity" (Art. 9). The intangible social and cultural dimension of urban heritage/landscape, the "atmosphere" and sense of place as perceived and created by local communities (past and present ones) contribute to the productivity of cities in a broad and multidimensional sense.

The HUL approach aims at "preserving the quality of the human environment, enhancing the productive and sustainable use of urban spaces, while recognizing their dynamic character, and promoting social and functional diversity" (Art. 11). 
It introduces a paradigm shift from conservation as a "value in itself", to conservation as a "tool" for managing change while preserving cultural values. HUL advocates the development of tools to "manage physical and social transformations and to ensure that contemporary interventions are harmoniously integrated with heritage in a historic setting" (Art. 12): innovative civic engagement, knowledge and planning tools, financial tools and regulatory systems (Art. 24).

The assessment of multidimensional impacts of HUL conservation / regeneration on city productivity is fundamental to demonstrate the effectiveness of proposed tools, to inform policy design and leverage private and public investments.

The objective of this paper is to provide an overview and critical outlook of current evaluation tools for the implementation of the UNESCO Historic Urban Landscape approach, towards a comprehensive framework for impact assessment of HUL conservation / regeneration. Section 2 provides a critical overview of existing tools, briefly analysing recent experiences of HUL implementation. In Section 3 we identify indicators categories and evaluation tools for multidimensional / multistakeholder impact assessment. Section 4 provides a critical discussion and open questions, proposing a possible framework for HUL impact assessment.

\section{EVALUATION TOOLS: THE NEED OF SPECIFIC APPROACHES}

Cultural heritage can be an effective catalyst for stimulating local and regional economies, producing significant economic impacts (Nypan, 2006; Rypkema, 2008).

The recent HUL Guidebook highlights that "successful management of urban heritage in complex environments demands a robust and continually evolving toolkit" (UNESCO, 2016, p.14). The guidelines identify specific tools based on the 2011 Recommendations: community engagement tools (Planning, GIS, Big data, Morphology, Impact / vulnerability assessment, Policy assessment), knowledge and planning tools (Publicity, Dialogue and consultation, Community empowerment, Cultural mapping), regulatory systems (Laws and regulations, Traditional custom, Policies and Plans), financial tools (Economics, Grants, Public-private cooperation).

Evaluation tools are not included between these tools. Evaluation processes should be considered in this framework as an additional fundamental category of management tools, currently almost unexplored in the field of HUL regeneration. They are necessary to manage the complex balance of conservation and development needs in Historic Urban Landscapes.

Tab. 1 shows six critical steps to facilitate the implementation of the HUL approach, highlighting the need of possible evaluation tools in each stage. 
Sectorial tools have been recently developed for heritage assessment, such as the ICOMOS Guidance for Heritage Impact Assessment (HIA) (ICOMOS, 2011), which provides a framework for the assessment of the impacts of urban transformations "on" the cultural value of properties.

The HIA Guidance has been applied in many cases (Pereira Roders and Van Oers, 2012) but it excludes the economic and social dimension of heritage regeneration. The HIA remains a sectorial framework unable to address the complex challenges of integrated impact assessment (Morrison-Saunders, et al., 2014; Pope, et al., 2013; Fusco Girard, et al., 2015).

Fig. 1 shows two possible approaches to impact assessment: impacts "on" the cultural value and the impacts "of" HUL for the enhancement of city productivity.

Table 1 - Six steps for making operational the Historic Urban Landscape approach - adapted from the HUL Guidebook (Source: UNESCO (2016))

\begin{tabular}{|l|l|l|}
\hline Phases & Activities & Possible proposed evaluation tools \\
\hline $\begin{array}{l}\text { 1. Identify } \\
\text { Resources }\end{array}$ & $\begin{array}{l}\text { Mapping and survey of cultural and } \\
\text { natural resources }\end{array}$ & $\begin{array}{l}\text { Spatial evaluation tools, surveys, community } \\
\text { involvement tools }\end{array}$ \\
\hline $\begin{array}{l}\text { 2. Identify } \\
\text { Attributes and } \\
\text { Values }\end{array}$ & $\begin{array}{l}\text { Involve stakeholders and experts in } \\
\text { the identification of attributes and } \\
\text { values of cultural and natural heritage }\end{array}$ & $\begin{array}{l}\text { Multistakeholder and multidimensional tools / } \\
\text { approaches (through Living Lab processes) }\end{array}$ \\
\hline $\begin{array}{l}\text { 3. Understand } \\
\text { vulnerability }\end{array}$ & $\begin{array}{l}\text { Assess vulnerability of heritage to } \\
\text { socio-economic stresses and climate } \\
\text { change }\end{array}$ & Multicriteria evaluation tools \\
\hline $\begin{array}{l}\text { 4. Planning and } \\
\text { design for } \\
\text { conservation / } \\
\text { regeneration }\end{array}$ & $\begin{array}{l}\text { Identify heritage sensitivity areas and } \\
\text { develop regeneration projects }\end{array}$ & $\begin{array}{l}\text { Spatial evaluation tools } \\
\text { Evaluation approaches for the assessment of } \\
\text { attractiveness }\end{array}$ \\
\hline 5. Prioritize & $\begin{array}{l}\text { Identify and prioritize actions for } \\
\text { conservation and development }\end{array}$ & $\begin{array}{l}\text { Multidimensional, multicriteria and } \\
\text { multistakeholder evaluation tools, cost- } \\
\text { effectiveness and benefit analysis }\end{array}$ \\
\hline 6. Realize & $\begin{array}{l}\text { Establish partnerships and local } \\
\text { management frameworks for each } \\
\text { project }\end{array}$ & $\begin{array}{l}\text { Monitoring tools } \\
\text { Financial tools } \\
\text { Cost-benefit analysis } \\
\text { New management / economic / business } \\
\text { models }\end{array}$ \\
\hline
\end{tabular}




\section{IMPACTS}

\section{ON HUL \\ "CULTURAL VALUE"}

Heritage Impact Assessment

State of Conservation of heritage properties, Perceived landscape quality

Non-use values, Impacts on Quality of Life
OF HUL

development / conservation /

regeneration:

"PRODUCTIVITY"

Quantitative / Qualitative / Monetary assessment through indicators

(multidimensional cost-benefit analysis)

Use values, Impacts on local economies, Public financial return, Wellbeing..

Figure 1 - Impacts of HUL conservation / regeneration on cultural value and overall city productivity

A similar approach has been adopted by UNESCO State of Conservation reports, which identify major threats to World Heritage properties (UNESCO, 2014). Buildings and development, social/cultural uses of heritage (such as tourism pressure) and transportation infrastructures represent threats to World Heritage properties. However, housing and public space enhancement, compatible heritage use and infrastructure can represent also key factors of sustainable development: it is only through the "project" that potential threats can be turned into social, cultural, environmental and economic benefits for communities, exploiting the full potential of HUL as a driver for sustainable growth, taking into account stakeholder and end-users needs/preferences. Adaptive re-use projects, new management and business models can enhance city productivity through HUL regeneration.

\subsection{Historic Urban Landscape evaluation: recent experiences}

The HUL Guidebook includes 8 case studies and best practice of HUL implementation: Ballarat, Australia; Shanghai, China; Suzhou, China; Cuenca, Ecuador; Rawalpindi, Pakistan; Zanzibar, Tanzania; Naples, Italy; Amsterdam, Netherlands. Only in few cases (Cuenca, Rawalpindi, Amsterdam) assessment methods has been proposed and experimented.

In the case of Cuenca, urban landscape units have been identified based on participative landscape quality assessment. Cultural values, heritage resources, recommendations and necessities of each unit has been the main output of the methodology.

In Rawalpindi, a vulnerability assessment has been carried out based on the outcomes of participative meetings and seminars and street level consultation. The result has been an understanding of the values of the historic city and the attributes which need to be safeguarded. Assessment of the vulnerability of these 
attributes to socio-economic pressures has been carried out focusing on built heritage, traditional occupations and bazaar resilience, cultural diversity and the religious landscape.

In Amsterdam, a more sophisticated taxonomy-based (classification) policy analysis tool has been applied to understand how urban policies in Amsterdam are being applied and used in relation to HUL. The tool has four taxonomy dimensions: attributes (what), values (why), actors (who), process (how). A matrix of "cross-relating taxonomy" has been used to analyse the different approaches of workshops' participants, mainly heritage and urban officers, to heritage regeneration.

These experiences have been focused on the assessment of characters and values of historic urban landscape, involving local communities and specific groups of stakeholder for vulnerability assessment and proposal of strategic action. In all these cases, the impacts of conservation / regeneration have not been addressed.

\section{TOWARDS A FRAMEWORK FOR MULTIDIMENSIONAL IMPACT ASSESSMENT OF HISTORIC URBAN LANDSCAPE}

Multicriteria, multidimensional and multistakeholder evaluation methods and sophisticated quantitative-qualitative indicators are needed to hybridize in a creative way tradition and modernity, memory and current action, conservation and transformation, turning the cultural value into a resource of city productivity.

Cost-benefit analysis can provide critical evidence base of the benefits of conservations vs. development, but multidimensional categories of costs and benefits should be introduced. Economic matrix is necessary, but not sufficient to assess the impacts of projects and investments in multiple dimensions. New tools for integrated cost-benefit analysis should be implemented to make operational the HUL approach (Ost, 2013; Fusco Girard, 2014b; De Rosa and Nocca, 2015; Garcia Vélez, et al., 2016).

Fusco Girard, et al. (2015) identify six categories of impact to assess the "productivity" of HUL conservation / regeneration, and thus the multidimensional benefits produced: Tourism and recreation, Creative and innovative activities, Typical local productions, Environment and Natural Capital, Community and social cohesion, Real estate. The cultural value of properties / landscape is introduced as a complex indicator based on the Heritage Impact Assessment matrix.

These comprehensive impact categories can be further integrated considering two key aspects of HUL regeneration: (1) the enhancement of wellbeing / welfare of communities and (2) financial returns of public investments.

A set of synthetic, measurable indicators is necessary to structure a comprehensive framework for a robust and richer cost-benefit / effectiveness analysis. The aim is to produce practical evidence of the cultural, economic, 
social and environmental benefits of HUL conservation / regeneration, assessing the economic, environmental and social return on investments based on quantiqualitative and economic analysis.

Evaluation tools for cultural heritage have undergone vast improvement in recent years (Rypkema, 2008; Ginsburgh and Throsby, 2014; Throsby, 2016). However, multidimensional cost-benefit analysis still have to be developed and tested. Sound methodology and good data are needed to assess the impacts generated by heritage conservation, considering market and non-market values (Vernieres, et al., 2012). To achieve this and promote evidence base for informed policies and investments in Historic Urban Landscape regeneration, existing barriers between disciplines must be overcome and integrated approaches developed.

Tab. 2 shows a proposal of indicator categories related to the multidimensional impacts identified.

Table 2 - Categories of impact of HUL conservation / regeneration and categories of indicators (Source: Adapted from Fusco Girard, et al. (2015))

\begin{tabular}{|c|c|}
\hline CATEGORY of IMPACTS & CATEGORIES of INDICATORS \\
\hline \multirow{5}{*}{$\begin{array}{l}\text { Tourism and Recreation } \\
\text { (cultural events and resident's } \\
\text { use of heritage) }\end{array}$} & Tourism demand / supply (direct use of heritage) \\
\hline & Residents demand (direct use of heritage) \\
\hline & Cultural facilities, services and events demand / supply \\
\hline & Tourism facitilities, retail and services demand / supply \\
\hline & Employment in tourism sector \\
\hline \multirow{2}{*}{$\begin{array}{l}\text { Creative and cultural / } \\
\text { innovative activities }\end{array}$} & Growth of Creative Industries \\
\hline & Employment in the Creative Economy \\
\hline \multirow{3}{*}{$\begin{array}{l}\text { Typical food\&beverage local } \\
\text { productions }\end{array}$} & Market value of typical food\&beverage products \\
\hline & Growth of food\&beverage companies \\
\hline & Employment in the typical food\&beverage industry \\
\hline \multirow{4}{*}{$\begin{array}{l}\text { Environment and Natural } \\
\text { Capital (natural heritage, } \\
\text { cultural landscapes) }\end{array}$} & Green areas and facitilies use / supply \\
\hline & $\begin{array}{l}\text { Economic value of Ecosystem / Landscape Services (direct use } \\
\text { values: provisioning services) }\end{array}$ \\
\hline & Energy savings \\
\hline & $\begin{array}{l}\text { Ecosystem preservation - Economic value of Ecosystem / Landscape } \\
\text { Services (indirect use values: support services, regulating and } \\
\text { maintenance services) }\end{array}$ \\
\hline \multirow{4}{*}{$\begin{array}{l}\text { Community and Social } \\
\text { Cohesion }\end{array}$} & Sharing / Collaborative economy \\
\hline & Donations for heritage conservation \\
\hline & Social care \\
\hline & Social cohesion \\
\hline \multirow[t]{4}{*}{ Real estate } & Real estate values \\
\hline & $\begin{array}{l}\text { Urban growth (infrastructure, land use change, public space } \\
\text { enhancement) }\end{array}$ \\
\hline & $\begin{array}{l}\text { Urban renewal (restoration, adaptation of historic buildings, } \\
\text { reduction of vacancy rates) }\end{array}$ \\
\hline & Employment in real estate sector \\
\hline
\end{tabular}




\begin{tabular}{|l|l|}
\hline CATEGORY of IMPACTS & CATEGORIES of INDICATORS \\
\hline Welfare / wellbeing & Poverty alleviation \\
\cline { 2 - 2 } & Sanitation \\
\cline { 2 - 2 } & Crime reduction \\
\cline { 2 - 2 } & Improved public safety (perceived) \\
\cline { 2 - 2 } & Improved wellbeing (perceived) \\
\cline { 2 - 2 } & Improved cultural benefit (perceived) \\
\cline { 2 - 2 } & Landscape quality (perceived) \\
\hline Public financial return & Fiscal revenues \\
\cline { 2 - 2 } landscape & Attraction of private investments \\
\hline Cultural value of properties / & State of conservation \\
\cline { 2 - 2 } & HIA synthetic indicator (1 to 5 value) \\
\cline { 2 - 2 } & Intrinsic value \\
\cline { 2 - 2 } & $\begin{array}{l}\text { Economic value of Ecosystem / Landscape Services } \\
\text { (cultural services - non use values) }\end{array}$ \\
\hline
\end{tabular}

Indicators for the assessment of tourism and real estate impacts have been implemented in many experiences, while indicators of environment and natural capital, community and social cohesion, public financial return, welfare/wellbeing still need further research and case study testing. We focus here on wellbeing indicators recently developed and tested in Italy.

Stakeholders' analysis should be integrated in the framework. We analyse the method of Community Impact Evaluation towards a comprehensive framework that takes into account costs and benefits for all stakeholder groups in the perspective of effective HUL management.

\subsection{BES indicators of Sustainable and Equitable Wellbeing}

The indicators of "Sustainable and Equitable Wellbeing" (BES) have been developed by the Italian National Institute for Statistics providing annual reports at the national and city level (ISTAT, 2015a; ISTAT, 2015b). The BES framework identifies 12 domains of wellbeing and 134 indicators, monitored on an annual base using nationally aggregated data as well as local data. The BES project links with the international debate on "GDP and beyond" (Stiglitz, Sen and Fitoussi, 2009; Costanza, et al., 2009; European Commission, 2009; Bartelmus, 2014), the central idea is that economic parameters alone are inadequate to evaluate the progress of societies and should be complemented by social and environmental information and by measures of inequality and sustainability. The 12 domains of wellbeing are showed in Tab. 3 . 
Table 3 - BES Wellbeing domains (Source: Adapted from ISTAT (2015a))

\begin{tabular}{|c|c|}
\hline \multicolumn{2}{|l|}{ The individual sphere } \\
\hline 1. Environment & 5. Work - life balance \\
\hline 2. Health & 6. Social relationships \\
\hline 3. Economic well-being & 7. Safety \\
\hline 4. Education and training & 8. Subjective well-being \\
\hline \multicolumn{2}{|l|}{ The context } \\
\hline 9. Landscape and cultural heritage & 11. Quality of services \\
\hline 10. Research and innovation & 12. Policies and institutions \\
\hline
\end{tabular}

The BES framework explicitly includes the domain of "Landscape and cultural heritage" in the contextual indicators of wellbeing, an innovative approach compared to other well-established indexes developed worldwide such as: the Canadian Index of Wellbeing, Capability Index, the EU Set of Sustainable Development Indicators, European Benchmark Indicators, Genuine Progress Indicator, Happy Planet Index, Human Development Index, Index of Living Conditions, JFS Sustainability Vision and Indicators, MDG Dashboard of Sustainability, Millennium Development Goals Index, Sustainable National Income, World Happiness index, National Accounts of Well-Being (European Commission, 2016).

Tab. 4 reports the indicators used in the BES for the measurement of landscape and cultural heritage component of wellbeing. These include subjective and objective indicators, which data are collected through annual national surveys.

Table 4-BES Landscape and cultural heritage indicators (Source: Adapted from ISTAT (2015a))

\begin{tabular}{|c|c|}
\hline \multicolumn{2}{|c|}{ BES Domain 9. Landscape and cultural heritage indicators } \\
\hline \multirow{9}{*}{$\begin{array}{l}\text { Objective } \\
\text { indicators }\end{array}$} & Endowment of cultural heritage items \\
\hline & $\begin{array}{l}\text { Current expenditure of municipalities for the management } \\
\text { of cultural heritage }\end{array}$ \\
\hline & Illegal building rate \\
\hline & $\begin{array}{l}\text { Urbanization rate of areas subject to building restrictions by } \\
\text { virtue of the Italian laws on landscape protection }\end{array}$ \\
\hline & Erosion of farmland from urban sprawl \\
\hline & Erosion of farmland from abandonment \\
\hline & Presence of historic rural landscapes \\
\hline & $\begin{array}{l}\text { Presence of Historic Parks/Gardens and other Urban Parks } \\
\text { recognized of significant public interest }\end{array}$ \\
\hline & Conservation of historic urban fabric \\
\hline
\end{tabular}


BES Domain 9. Landscape and cultural heritage indicators

\begin{tabular}{l|l}
\hline Expert & Quality assessment of regional programmes for rural development (PSRs), with regard to
\end{tabular} assessment the landscape protection

\begin{tabular}{|l|l}
\hline Subjective & People who are not satisfied with the quality of landscape of the place where they live
\end{tabular}

indicators

Concern about landscape deterioration

The BES (national level), UrBES (city level) and Provincial BES experiences demonstrate how local-national data and subjective-objective indicators can be used in a comprehensive framework for the monitoring of multiple benefits of HUL regeneration.

\subsection{Towards a Community Impact Evaluation (CIE) revised approach}

The Community Impact Evaluation (CIE) has been proposed by Lichfield to allow for quantitative-qualitative impact evaluation of projects/programmes, considering costs and benefits to directly and indirectly involved stakeholder groups (Fusco Girard and Nijkamp, 1997; Lichfield, 2005). A revised CIE approach (Fusco Girard, et al., 2016) can be applied for the assessment of HUL regeneration projects, using matrices that include stakeholders categories and objectives / criteria / indicators related to project scenarios, integrating quantitative monetary and non-monetary data (hard data) with qualitative / perceptual data (soft data). Stakeholder analysis should include the categories of promoters and producers/operators (policy-makers, local authorities, private companies, workers, associations, project related businesses), as well as consumers/users (residents, visitors, local businesses). Ost (2012) identifies four main categories of stakeholders involved in heritage regeneration: residents; visitors; population at large; business, shops and services. Tab. 5 proposes a classification of stakeholders involved in HUL regeneration projects

Table 5 - Stakeholders categories involved in HUL regeneration projects (Source: Adapted from Ost (2012) and Lichfield (2005))

\begin{tabular}{|c|c|}
\hline Category & Group \\
\hline \multirow{8}{*}{$\begin{array}{l}\text { Promoters, } \\
\text { Producers/Operators }\end{array}$} & Local authorities \\
\hline & Developers/Financiers \\
\hline & Conservation employees \\
\hline & Construction industry employees \\
\hline & Cultural associations \\
\hline & Foundations \\
\hline & Craftmen/farmers \\
\hline & Tourism-related businesses \\
\hline \multirow[t]{2}{*}{ Consumers/Users } & Local businesses / shops / street vendors \\
\hline & Local owners \\
\hline
\end{tabular}




\begin{tabular}{|l|l|}
\hline Category & Group \\
\hline & Local residents / occupiers \\
\cline { 2 - 3 } & New residents \\
\cline { 2 - 2 } & Users of heritage \\
\cline { 2 - 2 } & Visitors / tourists \\
\cline { 2 - 2 } & Passers-by \\
\cline { 2 - 2 } & Heritage community \\
\cline { 2 - 2 } & Local community \\
\cline { 2 - 2 } & Community at large \\
\hline
\end{tabular}

The costs and benefits for each stakeholders group (other groups can be added based on the specific project/programme) should be assessed to process a comprehensive evaluation of development versus conservation/regeneration projects, in order to find possible balances between conflicting interests.

\section{DISCUSSION AND CONCLUSIONS}

Though some evaluation tools have been applied in institutional and academic contexts, more research has to be carried out to test effective evaluation tools to manage historic urban landscapes.

Community involvement, vulnerability assessment and mapping tools are necessary, but not sufficient to promote more informed decision making and investments in HUL conservation / regeneration. The experiences analysed show how cultural value can be assessed, but this value should be turned into a resource for economic, social and environmental local development.

Cost-benefit analysis has been processed in the case of World Bank heritage regeneration projects (Licciardi and Amirtahmasebi, 2012; Ginsburgh and Throsby, 2014; Throsby, 2016), UNESCO properties and other cases of investment in historic centres and cultural landscapes regeneration (Rypkema, 2008; De Rosa and Nocca, 2015; Ost, 2012; Gravagnuolo, 2015; Fusco Girard, et al., 2015). These experiences demonstrate the potential of HUL as a driver of sustainable development. However, a structured process for integrated impact assessment, community impact assessment and multidimensional cost-benefit analysis and has still to be implemented.

Fig. 2 shows how a comprehensive framework for impact assessment can be developed, considering the cultural value of HUL, the multidimensional categories of impact, BES indicators and the CIE methodology. The aim is to provide a knowledge base and empirical evidence for informed, effective and wise management of historic urban landscapes. 


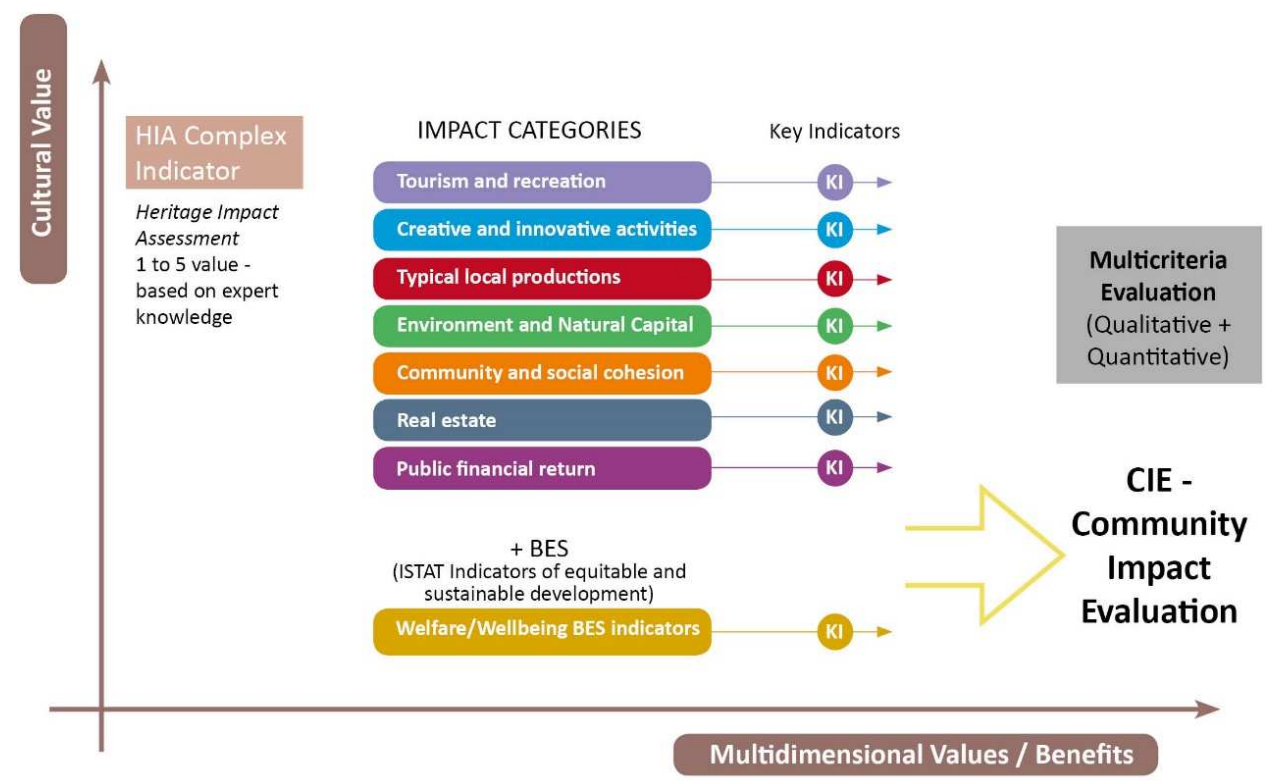

Figure 2 - Towards a comprehensive framework for impact evaluation of HUL conservation / regeneration (Source: Adapted from Fusco Girard, et al. (2015))

Effective, measurable and comparable indicators for HUL assessment should be developed, considering many open research questions:

1) the assessment of costs and benefits and assessment methods for each category of impact;

2) the need of objective, but also subjective indicators, which should be comparable throughout different countries and cultures;

3) the integration of quantitative and qualitative indicators, to assess the sustainability of the benefits produced;

4) the possibility to assess monetary values of non-economic indicators;

5) measurability and reliable / dynamic data sources at the national and regional / city level, and how to aggregate data;

6) stakeholders analysis and involvement in the evaluation process.

Evidence based, wise management of change should be supported by appropriate evaluation methods to promote urban planning and local development strategies that are cultural heritage-led, which enrich the ancient city in a way consistent with the vision of "good city" for all: that is a prosperous city, a "beauty" city, a city of fairness. This is a key dimension of sustainability, and is the way to achieve inclusion, safety, resilience.

The impact categories and methods proposed can represent a starting point for an integrated assessment framework to make operational the Historic Urban 
Landscape approach producing evidence base on the contribution of cultural heritage to sustainable development and wellbeing.

\section{ACKNOWLEDGMENTS}

This research is carried out within the Italian National Research Council, Research Institute on Innovation and Services for Development (CNR IRISS). This paper represents a synthesis of the discussions held during a series of seminars and meetings including Historic Urban Landscape international workshops in Naples in 2015 and 2016, "Smart Labs", UN public consultation on SDGs indicators and ICOMOS meetings towards Habitat III.

\section{REFERENCES}

Bandarin, F. and Van Oers, R., 2012. The historic urban landscape: managing heritage in an urban century. Hoboken: Wiley-Blackwell.

Bandarin, F. and Van Oers, R., 2014. Reconnecting the city: the historic urban landscape approach and the future of urban heritage. Hoboken: WileyBlackwell.

Bartelmus, P., 2014. What's Beyond GDP? Human Dimensions. Magazine of the International Human Dimensions Programme on Global Environmental Change, 1(4), pp.8-13.

Costanza, R., Hart, M., Posner, S. and Talberth, J., 2009. Beyond GDP: The Need for New Measures of Progress. The Pardee Papers. 4, pp.1-46. Available at: <www.bu.edu/pardee > [Accessed 24 November 2016].

De Rosa, F. and Nocca, F., 2015. Sustainable development and urban conservation: the challenge of Historic Urban Landscape. Housing Policies and Urban Economics, 2(1), pp.15-30.

European Commission, 2009. GDP and beyond. Measuring progress in a changing world. [pdf] Brussels: European Commission. Available at: $<$ http://ec.europa.eu/eurostat/cros/system/files/06_GDP\%20and\%20beyond.pdf> [Accessed 24 November 2016].

European Commission, 2014. Towards an integrated approach to cultural heritage for Europe. [pdf] Brussels: European Commission. Available at: $<$ http://ec.europa.eu/assets/eac/culture/library/publications/2014-heritagecommunication_en.pdf $>$ [Accessed 24 November 2016].

European Commission, 2016. Beyond GDP Measuring progress, true wealth, and well-being. indicators debate. Indicators. [pdf] Brussels: European Commission. Available at: $<$ http://ec.europa.eu/environment/beyond_gdp/indicators_wellbeing_en> [Accessed 24 November 2016]. 
Fusco Girard, L. and Nijkamp, P. eds., 1997. Le valutazioni per lo sviluppo sostenibile della città e del territorio. Milano, Italy: Franco Angeli.

Fusco Girard, L., 2014a. Editorial. BDC. Bollettino Del Centro Calza Bini, 14(2), pp.243-249.

Fusco Girard, L., 2014b. The role of cultural urban landscape towards a new urban economics: new structural assets for increasing economic productivity through hybrid processes. Housing Policies and Urban Economics, 1(1), pp.3-27.

Fusco Girard, L., Angrisano, M., Biancamano, P.F., Bosone, M., Carone, P., Daldanise, G., De Rosa, F., Franciosa, A., Gravagnuolo, A., Iodice, S., Nocca, F., Onesti, A., Panaro, S., Ragozino, S., Sannicandro, V., 2016. Towards operationalizing UNESCO Recommendations on "Historic Urban Landscape": a position paper. Aestimum, 69, pp.165-210.

Fusco Girard, L., Gravagnuolo, A., Nocca, F., Angrisano, M. and Bosone, M., 2015. Towards an economic impact assessment framework for Historic Urban Landscape conservation and regeneration projects. BDC Bollettino Del Centro Calza Bini, 15(2), pp.1-29.

Garcia Vélez, G., Carofilis, N., Ost, Ch. and Van Balen, K., 2016. Towards a Contemporary Approach to the study of Development and Cultural Heritage. In: K. Van Balen and A. Vandesande, eds. 2016. Heritage Counts. Leuven, Belgium: Garant Publishers. pp. 65-75.

Ginsburgh, V.A. and Throsby, D., 014. Handbook of the Economics of Art and Culture Volume 2. Oxford: North Holland, Elsevier.

Gravagnuolo, A., 2015. La valutazione dei paesaggi culturali. Approcci e strumenti per la tutela e valorizzazione dei sistemi terrazzati. Naples, Italy: University of Naples.

ICOMOS, 2011. Guidance on Heritage Impact Assessments for Cultural World Heritage Properties. [pdf] ICOMOS. Available at: < https://www.icomos.org/world_heritage/HIA_20110201.pdf> [Accessed 24 November 2016].

ISTAT, 2015a. BES 2015. Il benessere equo e sostenibile in Italia. [pdf] Rome: Istituto nazionale di statistica. Available at: < http://www.istat.it/it/files/2015/12/Rapporto_BES_2015.pdf> [Accessed 24 November 2016].

ISTAT, 2015b. Rapporto UrBES. Il benessere equo e sostenibile nelle città 2015. [pdf] Rome: Sistema Statistico Nazionale. Available at: < https://www.istat.it/it/files/2013/06/Urbes_2013.pdf> [Accessed 24 November 2016].

Licciardi, G. and Amirtahmasebi, R. eds., 2012. The Economics of Uniqueness. lnvesting in Historic City Cores and Cultural Heritage Assets for Sustainable Development. [pdf] Washington, D.C.: The World Bank. Available at: 
$<$ http://siteresources.worldbank.org/EXTSDNET/Resources/Economics_of_Uniq ueness.pdf $>$ [Accessed 24 November 2016].

Lichfield, N., 2005. Community Impact Evaluation: Principles And Practice. London: Taylor and Francis e-Library.

Morrison-Saunders, A., Pope, J., Gunn, J.A.E., Bond, A. and Retief, F., 2014. Strengthening impact assessment: a call for integration and focus. Impact Assessment and Project Appraisal, 32(1), pp.2-8.

Nypan, T., 2006. Cultural Heritage Monuments and Historic buildings as value generators in a post-industrial economy. With emphasis on exploring the role of the sector as economic driver. Norway: Directorate for Cultural Heritage.

Ost, C., 2012. Mapping Heritage Economics for Spatial Analysis in Historic City Cores. In: G. Licciardi and R. Amirtahmasebi, eds. 2012. The Economics of Uniqueness. Investing in Historic City Cores and Cultural Heritage Assets for Sustainable Development. Washington, D.C.: The World Bank. pp.245-283.

Ost, C., 2013. Historic cities in emerging countries. Economics of conservation revisited. BDC Bollettino Del Centro Calza Bini, 13(1), pp.73-78.

Pereira Roders, A. and Van Oers, R., 2012. Guidance on heritage impact assessments: Learning from its application on World Heritage site management. Journal of Cultural Heritage Management and Sustainable Development, 2(2), pp.104-114.

Pope, J., Bond, A., Morrison-Saunders, A. and Retief, F., 2013. Advancing the theory and practice of impact assessment: Setting the research agenda. Environmental Impact Assessment Review, 41, pp.1-9.

Rypkema, D.D., 2008. Heritage Conservation and the Local Economy. Global Urban Development Magazine, [online] 4(1). Available at: $<$ http://www.globalurban.org/GUDMag08Vol4Iss1/Rypkema.htm> [Accessed 24 November 2016].

Stiglitz, J.E., Sen, A. and Fitoussi, J.-P., 2009. The measurement of economic performance and social progress revisited. [pdf] Paris: OFCE - Centre de recherché en économie de Sciences Po. Available at: < https://www.ofce.sciences-po.fr/pdf/dtravail/WP2009-33.pdf> [Accessed 24 November 2016].

Throsby, D., 2016. Investment in urban heritage conservation in developing countries: Concepts, methods and data. City, Culture and Society, 7(2), pp.81-86.

UNESCO, 2011. Recommendation on the Historic Urban Landscape, including a glossary of definitions. [pdf] UNESCO. Available at: <http://portal.unesco.org> [Accessed 29 June 2016].

UNESCO, 2014. State of Conservation of World Heritage Properties. A statistical analysis (1979-2013), UNESCO. 
UNESCO, 2015. UNESCO Global Report on Culture and Sustainable Urban Development. Concept note. [pdf] UNESCO. Available at: < http://www.unesco.org/fileadmin/MULTIMEDIA/HQ/CLT/images/Conceptnote_EN.pdf $>$ [Accessed 16 November 2016].

UNESCO, 2016. The HUL Guidebook. Managing heritage in dynamic and constantly changing urban environments A practical guide to UNESCO's Recommendation on the Historic Urban Landscape. [pdf] UNESCO. Available at: <http://historicurbanlandscape.com/index.php?classid=5355> [Accessed 16 November 2016].

UNITED NATIONS, 2015. Transforming our World: the 2030 Agenda for Sustainable Development. [online] Available at: $<$ https://sustainabledevelopment.un.org/post2015/transformingourworld $>$ [Accessed 16 November 2016].

Van Balen, K. and Vandesande, A. eds., 2016. Heritage counts, Reflections on Cultural Heritage Theories and Practices. London: Garant Publishers.

Vernieres, M. Patin, V., Mengin, Ch., Geronimi, V., Dalmas, L., Noel, J.-F. and Tsang King Sang, J., 2012. Methods for the Economic Valuation of Urban Heritage: A Sustainability - based Approach. A savoir, 13. France: Imprimerie de Montligeon.

\section{ABOUT AUTHORS}

Antonia Gravagnuolo is researcher at Institute for Research on Innovation and Services for Development (IRISS), National Research Council (CNR), member of ICOMOS Italy and "Laboratory of Research on Creative and Sustainable City", University of Naples Federico II a.gravagnuolo@iriss.cnr.it.

Luigi Fusco Girard is Professor of Evaluation methods and Environmental Economics at the University of Naples Federico II and former Director of the Interdepartmental Research Centre on Urban Planning "Alberto Calza Bini" girard@unina.it. 